\title{
Biofertilizer Formulation with Bioactivators Bacillus cereus on the Growth and Yeild of Upland Rice (Oryza sativa L.) in Peat Medium
}

\author{
Hapsoh, Wawan, Isna Rahma Dini*, and Devi Andriani \\ Department of Agrotechnology-Agriculture Faculty, Universitas Riau, Riau Indonesia \\ *Corresponding author's email: isna.rahmadini [AT] lecturer.unri.ac.id
}

\begin{abstract}
This study aims to test the bio-fertilizer formulation with Bacillus cereus bioactivator and to obtain the best bio-fertilizer formulation for the growth and yield of upland rice (Oryza sativa $L$.) in peat medium. The research was conducted in the experimental garden and Soil Science Laboratory, Faculty of Agriculture, University of Riau from July to October 2018. The study was carried out experimentally using a completely randomized design (RAL) with the treatment tested was the formulation of Bacillus cereus (F): F0: $100 \mathrm{ml}$ Bacillus cereus without formulation, F1: 100 $\mathrm{ml}$ Bacillus cereus inoculant $+74 \%$ bagasse $+13 \%$ dolomite $+13 \%$ zeolite, $\mathrm{F} 2: 100 \mathrm{ml}$ Bacillus cereus inoculant $+74 \%$ rice husk $+13 \%$ zeolite $+13 \%$ dolomite, F3: 100 ml inoculant Bacillus cereus $+74 \%$ solid $+13 \%$ dolomite $+13 \%$ zeolite, F4: 100 $\mathrm{ml}$ Bacillus cereus inoculant $+74 \%$ tkks $+13 \%$ zeolite $+13 \%$ dolomite. The data obtained were analyzed statistically using variance fingerprints. The average result of the analysis was continued with the BNJ test at the $5 \%$ level. The results showed that administration of Bacillus cereus without formulation and with the formulation of solid organic matter of rice husks, solids and oil palm empty bunches showed a good response to the amount of chlorophyll and yield of upland rice plants.
\end{abstract}

Keywords-Biofertilizer, Bacillus cereus, upland rice, peat.

\section{INTRODUCTION}

Rice (Oryza sativa L.) is a rice producing plant as the main staple food source and the most important food in Indonesia. The need for food increases every year in line with the increasing population of Indonesia. Rice production is currently experiencing a decline and has not been able to meet the needs of the Indonesian population. Based on data from [1], rice production in Riau Province in 2018 was 208.6 thousand tons of milled dry unhulled rice (GKG), while in 2019 rice production was 131,820 tons. This number has decreased by 20,270 tons or 13.33 percent. Limited productive land is one of the causes of the current decline in rice production, which has led to the expansion of agricultural land leading to marginal lands. One of them is peatland, which is currently being optimized for agricultural land, but its use only leads to the plantation sector and uses peat for food crops, especially in Riau province. Peatlands are one of the ecosystems that have a large enough potential to be developed as agricultural land. Upland rice is a food crop that has the potential to be developed on peatlands. The development of upland rice cultivation on peat land still has many obstacles so that the productivity is low. Low productivity on peatlands is caused by low nutrient availability, low base saturation but high KTK and low soil pH. [2] stated that rice cultivation on peatlands has several problems such as low soil fertility and alkaline saturation such as low $\mathrm{pH}$.

Increasing upland rice production cannot be separated from the role of fertilizer use as an important factor of production, however, the high price of inorganic fertilizers circulating in the community often makes farmers not fertilize regularly, therefore the growth and yield of plants is low. To achieve the target of high production value, fertilizer alternatives are needed that are environmentally friendly, economical, easy to obtain and are expected to improve soil properties and reduce the continuous use of inorganic fertilizers. One of the efforts to overcome this is by restoring soil fertility and assisting the absorption of nutrients by using a biofertilizer formulation (Biofertilizer) which is made from local microbes, namely Bacillus cereus with solid organic waste.

Bacillus cereus used in this study is classified as cellulolytic bacteria which can degrade cellulose. The Bacillus cereus used has a cellulolytic index of 2 and is able to ferment carbohydrates and reduce sugar [3]. The results of research [4], stated that Bacillus cereus was able to produce the IAA hormone of $6.0842 \mathrm{ppm}$ which could stimulate root growth. Application of bacteria without formulation has weaknesses, namely bacteria cannot last long, nutrition is not available for bacteria and application in the field and packaging is more difficult. The ingredients used in the formulation consist of solid organic waste, carriers and mixing materials that are useful as nutrients for bacteria which can maximize the survival ability of bacteria in the formulation and increase the activity of biological agents to control target organisms. This study aims to 
test the bio-fertilizer formulation with the bioactivator Bacillus cereus and to obtain the best bio-fertilizer formulation for the growth and yield of upland rice (Oryza sativa L.) in peat medium.

\section{MATERIALS AND METHODS}

The research was conducted at Experimental Garden, Faculty of Agriculture, Riau University, and Soil Science Laboratory, Faculty of Agriculture, Riau University, Street of Bina Widya Km 12.5 Simpang Baru Village, Tampan District, Pekanbaru City, Riau Province. The study was carried out experimentally using a completely randomized design (RAL) with the treatment tested was the formulation of Bacillus cereus (F): F0: $100 \mathrm{ml}$ of Bacillus cereus without formulation, F1: $100 \mathrm{ml}$ of inoculant Bacillus cereus $+74 \%$ bagasse $+13 \%$ dolomite $+13 \%$ zeolite, F2: $100 \mathrm{ml} \mathrm{Bacillus}$ cereus inoculant $+74 \%$ rice husk $+13 \%$ zeolite $+13 \%$ dolomite, F3: $100 \mathrm{ml}$ Bacillus cereus inoculant $+74 \%$ solid $+13 \%$ dolomite $+13 \%$ zeolite, F4: $100 \mathrm{ml}$ Bacillus cereus inoculant $+74 \%$ tkks $+13 \%$ zeolite $+13 \%$ dolomite.

\section{Refresh Bacillus cereus isolate}

Bacillus cereus rejuvenation is done by taking Bacillus cereus isolates using a loop needle. Bacillus cereus isolate was isolated on Nutrient Agar (NA) medium using the scratch method. A total of 1 ose of Bacillus cereus isolate was scratched on the surface of the NA medium in a petri dish. Furthermore, the isolates were put into polyethylene plastic measuring $15 \mathrm{~cm} \times 20 \mathrm{~cm}$, then the isolates were stored in a cool box measuring $81 \mathrm{~cm} \mathrm{x} 47 \mathrm{~cm}$ at a temperature of $27{ }^{\circ} \mathrm{C}$ and incubated for 48 hours. Then Bacillus cereus on NA media was taken with a loop needle and put into a $50 \mathrm{ml}$ erlenmenyer and incubated at room temperature for 24 hours. After 24 hours, Bacillus cereus which was in a $50 \mathrm{ml}$ erlenmenyer was put into a $500 \mathrm{ml}$ erlenmenyer containing Nutrient Broth (NB) media and incubated at room temperature for 2 hours.

\section{Preparation of Bacillus cereus Biofertilizer Formulation}

Bacillus cereus colonies, which were 3 days old, were harvested by centrifugation at a speed of 7,500 rpm at room temperature for 6 minutes. The bacterial spores were then washed with Sodium Broth (NB) medium, then washed again with 0.05 molar phosphate buffer saline (PBS) solution, $\mathrm{pH} 7.0$, incubated for 24 hours, and ready to be used for direct field testing on upland rice plants.

\section{Colony Count Formulation of Bacillus cereus}

The formulation of Bacillus cereus was incubated, the colony counted. As much as $1 \mathrm{~g}$ of Bacillus cereus formulation diluted with sterile distilled water from $10^{-1}$ dilution level to $10^{-7}$ dilution level. The dilution rate used for colony counting is the $10^{-7}$ dilution rate. A total of $1 \mathrm{ml}$ of formulation at a $10^{-7}$ dilution is dropped into a petri dish that already contains Nutrient Agar (NA) medium and then left to stand until the medium solidifies. After being incubated for 24 hours, then the colony count was carried out.

$$
\begin{aligned}
& \text { Population }=\frac{\boldsymbol{x}}{\boldsymbol{v} \cdot \boldsymbol{p}} \\
& \text { Note } \quad: \quad x=\text { the number of colonies at a given dilution } \\
& \mathrm{v}=\text { volume of the dispersed suspension }(\mathrm{ml}) \\
& \mathrm{p}=\text { the dilution factor }
\end{aligned}
$$

Table 1. Colony calculations of the Bacillus cereus formulation

\begin{tabular}{cc}
\hline Formulasion Bacillus cereus & Number of colonies $\mathbf{~ c f u / ~ m l ) ~}$ \\
\hline F1 : Bacillus cereus + bagasse & $7,9 \times 10^{7}$ \\
F2 Bacillus cereus + rice husk & $5,6 \times 10^{7}$ \\
F3 $:$ Bacillus cereus + solid & $12,8 \times 10^{7}$ \\
F4 : Bacillus cereus + TKKS & $9,9 \times 10^{7}$ \\
\hline
\end{tabular}

The parameters observed were photosynthetic rate, conductivity of stomata, $\mathrm{CO}_{2}$ concentration, transpiration rate, amount of chlorophyll, plant height, maximum number of tillers, number of productive tillers, harvesting age, panicle length, weight of 1000 pithy grains, percentage of well-filled grains and weight of milled dry unhulled rice. per clump. The data obtained were analyzed statistically using variance fingerprints. The average results of the analysis were continued with the BNJ test at the $5 \%$ level.

\section{RESULTS AND DISCUSSION}

\subsection{Physiological Responses}

The results of the analysis of variance showed that the application of biological fertilizers with the bioactivator Bacillus cereus had no significant effect on the rate of photosynthesis, the conductivity of stomata, the rate of transpiration and the concentration of $\mathrm{CO}_{2}$ in upland rice plants. However, it has a significant effect on the amount of chlorophyll of upland rice plants. The results of the physiological response further test with the honest real difference test (BNJ) at the 5\% level can be seen in Table 2 . 
Table 2. The physiological response of upland rice plants by providing bio-fertilizers with Bacillus cereus bioactivator based on solid organic waste.

\begin{tabular}{|c|c|c|c|c|c|}
\hline Treatment & $\begin{array}{c}\text { Photosyn } \\
\text { thesis Rate } \\
\left(\mu \mathrm{mol} \mathrm{CO}_{2}\right. \\
\left.\mathrm{m}^{-2} \mathrm{~s}^{-1}\right) \\
\end{array}$ & $\begin{array}{l}\text { Amount of } \\
\text { Chlorophyll } \\
\left(\mu \mathrm{mol} \mathrm{m}{ }^{-2}\right)\end{array}$ & $\begin{array}{c}\begin{array}{c}\text { Conductivity } \\
\text { of Stomata }\end{array} \\
\left(\mathrm{mol} \mathrm{H}_{2} \mathrm{O} \mathrm{m}^{-}\right. \\
\left.{ }^{2} \mathrm{~s}^{-1}\right) \\
\end{array}$ & $\begin{array}{c}\text { Transpiration } \\
\text { Rate } \\
\left(\mathrm{mmol} \mathrm{H}_{2} \mathrm{O} \mathrm{m}^{-2}\right. \\
\left.\mathbf{s}^{-1}\right)\end{array}$ & $\begin{array}{c}\mathrm{CO}_{2} \\
\text { concentration } \\
\left(\mu \mathrm{mol} \mathrm{CO}_{2}\right. \\
\left.\text { mol }^{-1}\right) \\
\end{array}$ \\
\hline $\begin{array}{l}\text { B. cereus } \\
\text { without } \\
\text { formulation }\end{array}$ & $14,79 \mathrm{a}$ & $21,80 \mathrm{ab}$ & $0,109 \mathrm{a}$ & $2,11 \mathrm{a}$ & 137,58 a \\
\hline B.cereus+bagasse & $14,32 \mathrm{a}$ & $17,57 \mathrm{c}$ & $0,098 \mathrm{a}$ & $1,94 \mathrm{a}$ & $125,30 \mathrm{a}$ \\
\hline $\begin{array}{l}\text { B.cereus+rice } \\
\text { husk }\end{array}$ & $15,53 \mathrm{a}$ & $19,07 \mathrm{ab}$ & $0,106 \mathrm{a}$ & $1,77 \mathrm{a}$ & $100,48 \mathrm{a}$ \\
\hline B.cereus+ solid & $15,49 \mathrm{a}$ & $20,95 \mathrm{ab}$ & $0,078 \mathrm{a}$ & $1,62 \mathrm{a}$ & $91,12 \mathrm{a}$ \\
\hline $\begin{array}{l}\text { B.cereus+bunches } \\
\text { empty palm oil }\end{array}$ & $13,64 \mathrm{a}$ & $23,13 \mathrm{a}$ & $0,096 \mathrm{a}$ & $1,68 \mathrm{a}$ & $104,63 \mathrm{a}$ \\
\hline
\end{tabular}

Note: The numbers followed by the same lowercase letter in the same column are not significantly different according to the honest real difference test (BNJ) at the $5 \%$ level.

Table 2 shows that the physiological responses of upland rice plants with the application of biological fertilizers with the bioactivator Bacillus cereus based on solid organic matter to the observed parameters of photosynthesis rate, stomata conductivity, transpiration rate and $\mathrm{CO}_{2}$ concentration gave insignificantly different results in all tested treatments but significantly different. on observing the amount of chlorophyll of upland rice plants. The average photosynthetic rate of rice plants ranged from $13.64-15.53 \mu \mathrm{mol} \mathrm{CO} \mathrm{CO}_{2}^{-2} \mathrm{~s}^{-1}$, the conductivity of the stomata ranged from $0.096-0.109 \mathrm{~mol} \mathrm{H}_{2} \mathrm{O}$ $\mathrm{m}^{-2} \mathrm{~s}^{-1}$, the transpiration rate ranged from 1.62- $2.11 \mathrm{mmol} \mathrm{H}_{2} \mathrm{O} \mathrm{m}^{-2} \mathrm{~s}^{-1}$ and $\mathrm{CO}_{2}$ concentrations ranging from 61.12-137.58 $\mu \mathrm{mol} \mathrm{CO}_{2}$ mol-1. It is suspected that when the plants undergo physiological processes, the Bacillus cereus used in the formulation of biological fertilizers given to upland rice plants is not fully active (still in a dormant state) so that it has not been able to produce secondary metabolics such as the IAA hormone. According to [5], the adaptation phase (lag phase) is the initial phase where at this time it is the adjustment of bacteria in a new environment. In this phase there is no increase in cells, but an increase in cell size.

Physiological processes occur in all plant organs such as those under the leaf surface (although some are above or even on both leaf surfaces) in which there are stomata cells that play a role in the processes of photosynthesis, respiration and tranpiration which in turn also affect metabolism and plant growth. The stomata response in high $\mathrm{CO}_{2}$ conditions has an important role because the opening of the stomata is closely related to $\mathrm{CO}_{2}$ fixation for the photosynthesis process. According to [6], the conductivity of the stomata is directly influenced by the size of the stomatal opening. The larger the open stomata, the higher the conductivity, otherwise the stomata will get a little outside air when the stomata openings are narrow.

The amount of chlorophyll of rice plants with the application of biofertilizer Bacillus cereus + oil palm empty bunches was significantly different from the application of Bacillus cereus + bagasse but not significantly different from other treatments. This is presumably due to the light intensity factor received by plants. Chlorophyll is the main component of chloroplasts and chlorophyll content is relatively positively correlated with the rate of photosynthesis [7]. Light intensity affects the photosynthesis process, because light will be absorbed by the photosystem consisting of chlorophyll a, chlorophyll $\mathrm{b}$, and complementary pigments. [8], stated that the content of chlorophyll a, chlorophyll b, and total chlorophyll at low light intensity is higher, because plants adapt to the absorption of a limited amount of light. The low light intensity factor can affect the size of the light harvesting pigment antenna to capture limited light.

The total chlorophyll content for the optimal rate of photosynthesis is not only affected by light intensity. In addition, genetic factors also influence the optimal rate of plant photosynthesis. Each type of plant responds differently to the intensity of light received at different rates of photosynthesis. According to [8], light intensity affects the activity of the light harvesting gene, causing each plant species to have a different response in activating the harvesting pigment gene according to the quantity of light received. Chlorophyll is synthesized in leaves and has a role to capture sunlight, the amount is different for each species. Chlorophyll synthesis is influenced by various factors such as light, sugar or carbohydrates, water, temperature, genetic factors, nutrients such as $\mathrm{N}, \mathrm{Mg}, \mathrm{Fe}, \mathrm{Mn}, \mathrm{Cu}, \mathrm{Zn}, \mathrm{S}$ and $\mathrm{O}$ [9].

\subsection{Growth response}

The results of the analysis of variety showed that the application of biological fertilizers with the bioactivator Bacillus cereus had no significant effect on plant height, maximum number of tillers, number of productive tillers, and age of harvest. The results of further growth response tests with the honest real difference test (BNJ) at the $5 \%$ level can be seen in Table 3. 
Table 3. The response to the growth of upland rice plants with the application of biological fertilizers with Bacillus cereus bioactivator based on solid organic waste.

\begin{tabular}{ccc}
\hline Treatment & Plant height (cm) & $\begin{array}{c}\text { Maximum number of } \\
\text { tillers (steam) }\end{array}$ \\
\hline Bacillus cereus without formulation & $104,88 \mathrm{a}$ & $19,18 \mathrm{a}$ \\
Bacillus cereus + bagasse & $105,00 \mathrm{a}$ & $19,31 \mathrm{a}$ \\
Bacillus cereus + rice husk & $106,56 \mathrm{a}$ & $18,81 \mathrm{a}$ \\
Bacillus cereus + solid & $105,06 \mathrm{a}$ & $18,44 \mathrm{a}$ \\
Bacillus cereus + bunches & $102,81 \mathrm{a}$ & $21,18 \mathrm{a}$ \\
\hline
\end{tabular}

Note : The numbers followed by the same lowercase letter in the same column are not significantly different according to the honest real difference test $(\mathrm{BNJ})$ at the $5 \%$ level.

The table shows that the growth response of upland rice plants with the application of bio-fertilizer formulation with solid organic waste-based Bacillus cereus bioactivator gave insignificantly different results in all treatments tested against the parameters of plant height and maximum number of tillers. The average height of upland rice plants ranged from 102.81 to $106.56 \mathrm{~cm}$ and the maximum number of tillers ranged from 18.44 to 21.18 rice stalks. This is presumably due to the low $\mathrm{pH}$ of the peat soil used, namely 4.38 where the $\mathrm{pH}$ is classified as acidic. The growth and development of bacteria must also be supported by an optimum and appropriate $\mathrm{pH}$. It is suspected that Bacillus cereus in biological fertilizers can grow but its ability is not yet effective because it cannot perform well in the formulation and conditions of peat soil that have an acidic $\mathrm{pH}$ so that its ability to produce IAA hormone is not optimal so that it does not make a real difference to all treatments tested.

According to [10] stated that the media $\mathrm{pH}$ that is better for bacterial growth and for the ability of bacteria to produce IAA is that the $\mathrm{pH}$ of the media is closer to neutral ( $\mathrm{pH} 7.0)$. The more acidic the $\mathrm{pH}$ of the medium in which the bacteria are grown, the less the ability of the bacteria to grow and produce IAA. In addition, the availability of macro nutrients in the soil is needed by plants in the metabolic process. Tillers are vegetative growth of plants. Several macro nutrients such as N, P, and K are needed by plants in metabolic processes. If macro nutrients, especially N, P, and K are not available in optimal amounts on peat soils, it will affect the formation of upland rice tillers. Nitrogen is an essential nutrient, making up $1.5 \%$ of the plant weight and functions primarily in the formation of protein. Protein is a building block for the cell nucleus and cell division. This process of cell division and elongation can increase the maximum number of upland rice tillers. [11] stated that $\mathrm{N}$ is a basic component of protein synthesis, part of chlorophyll and plays a role in the photosynthesis process which will be used in the process of forming plant branches. Furthermore, [12] stated that elemental $\mathrm{N}$ is an element that quickly affects plants, increases the number of tillers and increases the number of seeds per hill.

$\mathrm{P}$ and $\mathrm{K}$ elements are also indispensable for plants in metabolic processes. [13] state that the $\mathrm{P}$ element plays a role in increasing the number of productive tillers of rice, root development, early flowering and ripening, besides that the addition of P elements will strengthen the plant root system so that many tillers are produced. [14] added that the P element is important in the work efficiency of chloroplasts and plays an active role in transferring energy in cells which is very important in the process of cell division to form new offspring. [6] stated that the amount of nutrient needed is related to the need for plants to grow properly, if the nutrient elements are not available, plant growth will be stunted.

\subsection{Result Response}

The results of the analysis of variance showed that the application of bio-fertilizer formulation with the bioactivator Bacillus cereus had no significant effect on the observed parameters of panicle length, weight of 1000 pithy grains, number of pithy grains per hill and percentage of well-lined grains but had a significant effect on the weight of milled dry unhulled rice per clump of upland rice plants. . The results of the further test of the response to the results with the honest real difference test (BNJ) at the $5 \%$ level can be seen in Table 4.

Table 4 .Response of yield components and yields of upland rice by providing bio-fertilizer formulations with Bacillus cereus bioactivator based on solid organic waste.

\begin{tabular}{|c|c|c|c|c|c|c|c|}
\hline & & Number & & & The & & \\
\hline Trea & $\begin{array}{c}\text { Long } \\
\text { Panicle } \\
\text { (cm) }\end{array}$ & $\begin{array}{c}\text { of } \\
\text { produc- } \\
\text { tive } \\
\text { tillers } \\
\text { ( stem) }\end{array}$ & $\begin{array}{c}\text { Harvest } \\
\text { Age } \\
\text { (HST) }\end{array}$ & $\begin{array}{c}\text { Weight of } \\
1000 \\
\text { pithy } \\
\text { grains(g) }\end{array}$ & $\begin{array}{c}\text { number } \\
\text { of pithy } \\
\text { grains } \\
\text { per hill } \\
\text { (grain) }\end{array}$ & $\begin{array}{c}\text { Percentage } \\
\text { of pithy } \\
\text { grain }(\%)\end{array}$ & $\begin{array}{c}\text { Grain } \\
\text { weight } \\
\text { dry grind } \\
\text { per } \\
\text { clump (g) }\end{array}$ \\
\hline
\end{tabular}




\begin{tabular}{|c|c|c|c|c|c|c|c|}
\hline $\begin{array}{l}\text { B cereus } \\
\text { without } \\
\text { formulation }\end{array}$ & $26,30 \mathrm{a}$ & $15,62 \mathrm{a}$ & $106 \mathrm{a}$ & $26,29 \mathrm{a}$ & $4975,0 \mathrm{a}$ & $65,2 \mathrm{ab}$ & $37,79 \mathrm{a}$ \\
\hline $\begin{array}{l}\text { B. cereus }+ \\
\text { bagasse }\end{array}$ & $26,00 \mathrm{a}$ & $14,00 \mathrm{a}$ & $106 \mathrm{a}$ & $24,45 \mathrm{a}$ & $4312,5 \mathrm{a}$ & $59,75 \mathrm{c}$ & $31,27 \mathrm{c}$ \\
\hline $\begin{array}{l}\text { B. cereus + } \\
\text { rice husk }\end{array}$ & $27,65 \mathrm{a}$ & $13,56 \mathrm{a}$ & $106 \mathrm{a}$ & $26,19 \mathrm{a}$ & $4975,0 \mathrm{a}$ & $65,55 \mathrm{ab}$ & $35,58 \mathrm{ab}$ \\
\hline $\begin{array}{l}\text { B. cereus }+ \\
\text { solid }\end{array}$ & $26,96 \mathrm{a}$ & $14,87 \mathrm{a}$ & $106 \mathrm{a}$ & $26,24 \mathrm{a}$ & $5200,0 \mathrm{a}$ & $66,5 \mathrm{a}$ & $35,63 \mathrm{ab}$ \\
\hline $\begin{array}{l}\text { B.cereus+ } \\
\text { bunches } \\
\text { empty palm } \\
\text { oil }\end{array}$ & $27,62 \mathrm{a}$ & $12,12 \mathrm{a}$ & $106 \mathrm{a}$ & $25,47 \mathrm{a}$ & $4362,5 \mathrm{a}$ & $63,5 \mathrm{ab}$ & $34,98 \mathrm{ab}$ \\
\hline
\end{tabular}

Note : The numbers followed by the same lowercase letter in the same column are not significantly different according to the honest real difference test (BNJ) at the 5\% level.

Table 4 shows that the yield component response and yield of upland rice plants with the application of bio-fertilizer formulation with the bioactivator Bacillus cereus gave insignificantly different results on the observation of panicle length and weight of 1000 pithy grains but had a significant effect on the percentage of pithy grain and weight of dry grain. milled per clump of upland rice plants. This is presumably because the application of biological fertilizer formulations can provide sufficient nutrients for yield components and yields of upland rice plants. Macro and micro nutrients are needed in plant metabolic processes, especially when filling and forming plant seeds that can provide the expected results.

Panicle length growth is greatly influenced by cell elongation that occurs in plant physiological processes. Cell elongation requires energy in the form of ATP, one of which is the constituent element P. [6] stated that the P element plays a very important role in the formation of ATP which functions as an energy source in the process of plant metabolism. Energy in the form of ATP is formed in plant tissue which causes the formation of assimilates which will be translocated into grain. The ATP that is formed will trigger various biochemical processes in plant tissue such as elongation of plant cells which can trigger long panicle growth of upland rice plants. The results of the research [15] showed that giving 90 $\mathrm{kg} \cdot \mathrm{ha}^{-1}$ of $\mathrm{P}$ fertilizer was able to increase panicle length, namely $12.83 \mathrm{~cm}$ in wheat. The application of biological fertilizer formulations to the observed parameters of the number of productive tillers showed insignificant different results for all the treatments tested. This is because some solid organic waste has not been optimal in providing macro and micro nutrients in peat soils which have little availability. According to [16], some of the characteristics of biological fertilizers, one of which is the slow availability of nutrients, nutrients derived from organic matter are needed for microbial activity to be converted from organic complex bonds that cannot be utilized by plants so that they become simple bonds that can be utilized by plants. Organic fertilizers are generally complete fertilizers because they contain macro and micro elements even in small amounts.

Observation of the harvest age of upland rice plants with the application of biological fertilizer formulations showed insignificant differences in all the treatments tested. This is presumably because the harvest age is more influenced by genetic factors (varieties) and environmental factors in the place of research (temperature and altitude). [17] stated that the harvest age of plants is determined by several factors, namely the variety and the height of the planting site. One of the requirements for the release of upland rice varieties is carried out by means of multilocation tests in 8 different locations to obtain variety description data [18]. This causes the harvest age between the descriptions and the results of the research conducted differently. It is suspected that the temperature used in the study is higher than the temperature at the research location in the description. Observation of the weight of 1000 pithy grains and the percentage of pithy unhulled rice with the application of biological fertilizers gave an insignificant difference to all the treatments tested but gave 1000 pithy grain weight results that were better than the description of rice plants. This is presumably because the biological fertilizers provided have provided sufficient macro and micro nutrients to replenish the seeds of rice plants. Macro nutrients, especially P nutrients. The results of soil analysis showed that the $\mathrm{P}$ nutrient content ranged from $756-1397 \mathrm{ppm}$. This amount is sufficient for the need for $\mathrm{P}$ nutrients in the soil for upland rice plants. Element $\mathrm{P}$ is an essential element for plants because it is a limiting factor that affects plant growth and production. [19] stated that in rice plants the element of $\mathrm{P}$ plays a role in encouraging root growth and development, triggering flowering and fruit ripening, especially in low climatic conditions, encouraging more clump formation or tillers which allow faster recovery and adaptation when rice plants experience stress and supports the formation of better grain grains and has a better nutritional content with respect to the $\mathrm{P}$ content in the seeds.

Observation of the amount of pithy unhulled rice with the application of biological fertilizers gave insignificant differences between the treatments tested. It is assumed that environmental temperature and genetic factors greatly influence the time of filling grain, this is in accordance with the opinion of [20] reported that the character of the number of pithy grains and the number of grains was strongly influenced by genetic factors. The environmental average temperature 
is also a limiting factor in various grain formation and development processes, such as grain filling and dry matter production rate [21].

Observation of milled dry grain weight per clump with the application of biological fertilizer showed that Bacillus cereus without formulation was significantly different from the application of Bacillus cereus + bagasse but not significantly different from the treatment of Bacillus cereus + rice husk, Bacillus cereus + solid and Bacillus cereus + oil palm empty bunches. The weight of milled dry grain of rice plants is closely related to the amount of chlorophyll produced in rice plants because the amount of chlorophyll produced by plants is positively correlated with the rate of the plant's photosynthesis process. The application of biological fertilizers with the bioactivator Bacillus cereus + bagasse showed the lowest weight of milled dry grain per hill compared to other treatments. This is because bagasse has not been able to meet nutrient needs, especially in the process of replenishing rice seeds compared to other treatments. Bagasse has a more complex content compared to other organic materials. According to [22], bagasse cannot be directly fermented by microbes because it contains a lot of cellulose, hemicellulose and lignin which are complex compounds, so that the nutrient content is slowly available in the soil for replenishing rice seeds.

The ability of plants to be able to produce the number of filled grains per panicle is influenced by several factors. One of the most important factors is panicle length and nutrient availability. The difference in panicle length affects the difference in the number of grain seeds and the longer the panicles, the more grain will be formed. In addition, environmental factors also play a role in the high and low number of grain per panicle, because optimum light can increase the rate of photosynthesis [23].

\section{CONCLUSION}

The application of biological fertilizers with Bacillus cereus bioactivator formulated with solid organic matter and without formulation has not had a significant effect on parameters (photosynthetic rate, transpiration rate, $\mathrm{CO}_{2}$ concentration, stomatal conductivity, plant height, number of productive tillers, panicle length, maximum number of tillers. age of harvest, weight of 1000 pithy unhulled unhulled rice, number of pithy unhulled rice per clump and percentage of pithy unhulled rice) but significantly affected the amount of chlorophyll and weight of milled dry grain per hill of upland rice.

The application of biological fertilizers with the bioactivator Bacillus cereus without formulation and with the formulation of solid organic matter of rice husks, solids and oil palm empty bunches showed a good response to the amount of chlorophyll and yield of upland rice plants.

\section{ACKNOWLEDGMENT}

Thank you to the Universitas Riau through a professor's grant which has funded this research.

\section{REFERENCES}

[1] BPS-Statistics Indonesia, Riau dalam Angka BPS-Statistics Indonesia, Jakarta, 2019.

[2] Simbolon, "Peat swamp forest ecosistem: an important ecosistem and regional spatial planning. Scientific exploration and sustain-nable management of peat lands resources in giam siak kecil-bukit batu biosphere reserve", Pekanbaru, Riau, 4-5 August 2009, 2009.

[3] Hapsoh, Wawan and I.R. Dini, “Application of organic fertilizer with microbial technology supports sustainable integrated agriculture based on food crops on peatlands". University of Riau LPPM Competency Grant Final Report. Pekanbaru, 2016.

[4] Sri, W., Suliasih and Saefudin, "Isolation and testing the effectiveness of plant growth promoting rhizobacteria on marginal land on soybean plant growth (Glycine max L. Merr) var. Wilis". Proceedings of the National Seminar on the Indonesian Biodiversity Society vol.1, no.1, pp. 59-65, 2015.

[5] Dwidjoseputro, D, "Microbiology fundamentals", Djambatan, Jakarta, 2005.

[6] Lakitan, B, "Plant physiology fundamentals" PT. Grafindo Persada, Jakarta, 2012.

[7] Li, R., P. Guo, M. Baum, S. Grando and S. Ceccarelli "Evaluation of chlorophyll content and fluorescence parameters as indicators of drought tolerance in barley". Agricultural Sciences in China vol. 5, no 10, pp 751-757, 2006.

[8] Anni, I.A., E. Saptiningsih and S. Haryanti "Effect of shade on growth and production of leeks (Allium fistulosum L.) in Bandungan, Jawa Tengah". Jurnal Biologi vol. 2, no 3, pp 31-400, 2013.

[9] Hendriyani, I.S. and N. Setiari, "Chlorophyll content and growth of long beans (Vigna sinensis L.) at different water supply levels". Jurnal Sains \& Mat vol. 17, no. 3, pp 145-150, 2009.

[10] Agustian., Nuriyani, L.Maira and O. Emalinda, "Rhizobacteria that produce IAA phytohormones in the rhizosphere of Karamunting Shrubs, Titonia, and Food Crops". Jurnal Solum vol. 7, no.1, pp 49-60, 2010.

[11] Subhan, Nurtika N., Gunadi, N, "Response of tomato plants to the use of compound fertilizer NPK 15-15-15 on latosol soil in the dry season". Jurnal Hortikultura vol. 19, no. 1, pp 40-48, 2009. 
[12] Rauf, A., W.T. Syamsuddin dan S. R. Sihombing, "The role of NPK fertilizer in rice plants" Departemen Pertanian Badan Penelitian dan Pengembangan Pertanian, No.O1/LPTP/IRJA199-00, 2000.

[13] Dobermann, A dan T. Fairhust, "Rice nutrient disorders \& nutrient management" International Rice Research Institute (IRRI). Zinc Deficiency And Potash \& Phosphate Institute/Potash \& Phosphate Institute Of Canada. 8487pp, 2000.

[14] Riyani, R., Radiyan., S. Budi "Effect of various organic fertilizers on rice growth and yield in tidal land". Universitas Tanjungpura, Pontianak, 2012.

[15] Noonari, S., Kalhoro, S.A., Ali, A., Mahar, A., Raza, S., Ahmed, M., Shah, S.F.A. and Baloeh, S.U, "Effect of different levels of phosphorus and method of application on the growth and yield or wheat". Natural Science no.8, pp 305-314, 2016.

[16] Sutanto, R, “Application of organic agriculture: correctional and its development”. Kanisus, Yogyakarta, 2000.

[17] Fachruddin, "Cultivation of nuts”. Kanisius, Yogyakarta, 2000.

[18] Hairmainsis, A., Supartopo, Yulianida, A. Nasution, Santoso dan Suwarno, "New superior varieties of upland rice tolerant shade for rice cultivation as intercrops in plantations". Balai Besar Penelitian Tanaman Padi, 2017.

[19] Aisyah dan Parnata, "Increase yield with organic fertilizer". Agromedia Pustaka, Jakarta, 2010.

[20] Wirnas, D., Widodo,I., Sobir, Trikoesoemaningtyas., Sopandie, D, "Selection of selection characters to construct a selection index in 11 soybean populations of the F6 generation". Bul. Agron no. 34, pp 19-24, 2006.

[21] Wang, Y.W., Zhai, P.M, Tian, H, "Extreme high temperatures in southern China in 2003 under the background of climate change". Meteorol Mon vol. 32, no. 10, pp 27-33, 2006.

[22] Septiani, R, "The Effect of cellulase enzyme concentration and incubation time on sugar levels of sugarcane bagasse reduction".Skripsi Teknologi Hasil Pertanian (Tidak dipublikasikan). Universitas Lampung. Lampung, 2011.

[23] Setiawati, M.R. Emma, T.S. Zaenal, M, "Effect of solid biofertilizer on plant N and P Uptake, Yield Components and Rice Yield (Oryza sativa L.)”. Jurnal Agroekotek vol. 8, no 2, pp 120-130, 2016. 